University of New Hampshire

University of New Hampshire Scholars' Repository

$10-1-2003$

\title{
Warming winters and New Hampshire's lost ski areas: An integrated case study
}

\author{
Lawrence C. Hamilton \\ University of New Hampshire, Durham, lawrence.hamilton@unh.edu \\ David E. Rohall \\ Western Illinois University \\ Gregg F. Hayward \\ University of New Hampshire, Durham \\ Barry D. Keim \\ Louisiana State University, Baton Rouge
}

Follow this and additional works at: https://scholars.unh.edu/soc_facpub

Part of the Sociology Commons

\section{Comments}

This is an Author's Original Manuscript of an article published by Emerald Publishing in International Journal of Sociology and Social Policy on 2003, available online: https://dx.doi.org/10.1108/01443330310790309

\section{Recommended Citation}

Hamilton, L.C., D.E. Rohall, B.C. Brown, G. Hayward \& B.D. Keim. 2003. "Warming winters and New Hampshire's lost ski areas: An integrated case study." International Journal of Sociology and Social Policy 23(10):52-73.

This Article is brought to you for free and open access by the Sociology at University of New Hampshire Scholars' Repository. It has been accepted for inclusion in Sociology Scholarship by an authorized administrator of University of New Hampshire Scholars' Repository. For more information, please contact Scholarly.Communication@unh.edu. 
AUTHORS' DRAFT. Final version published at:

Hamilton, L.C., D.E. Rohall, B.C. Brown, G. Hayward \& B.D. Keim. 2003. "Warming winters and New Hampshire's lost ski areas: An integrated case study." International Journal of Sociology and Social Policy 23(10):52-73.

\title{
WARMING WINTERS AND NEW HAMPSHIRE'S LOST SKI AREAS
}

Lawrence C. Hamilton

David E. Rohall

Cliff Brown

Gregg Hayward

Barry D. Keim

Acknowledgments: This research has been supported through a grant from the National Oceanic and Atmospheric Administration (NOAA).

\begin{abstract}
New Hampshire's mountains and winter climate support a ski industry that contributes substantially to the state economy. Through more than 70 years of history, this industry has adapted and changed with its host society. The climate itself has changed during this period too, in ways that influenced the ski industry's development. During the 20th century, New Hampshire's mean winter temperature warmed about $2.1^{\circ} \mathrm{C}\left(3.8^{\circ} \mathrm{F}\right)$. Much of that change occurred since 1970 . The multidecadal variations in New Hampshire winters follow global temperature trends. Downward trends in snowfall, strongest in southern New Hampshire, also correlate with the North Atlantic Oscillation. Many small ski areas opened during the early years while winters were cold and snowy. As winters warmed, areas in southern or low-elevation locations faced a critical disadvantage. Under pressure from both climate and competition, the number of small ski areas leveled off and then fell steeply after 1970. The number of larger, chairlift-operating ski areas began falling too after 1980. A prolonged warming period increased the importance of geographic advantages, and also of capital investment in snowmaking, grooming and economic diversification. The consolidation trend continues today. Most of the surviving ski areas are located in the northern mountains. Elsewhere around the state, one can find the remains of "lost" ski areas in places that now rarely have snow suitable for downhill skiing.
\end{abstract}




\section{INTRODUCTION}

The first "human dimensions" contributions to global-change research involved speculation about possible impacts of future climatic change, built atop natural scientists' forecasts. Such work has obvious value, but remains incomplete as a research strategy. It lacks an observational component analogous to the empirical work that has been so critical in advancing natural-science climate research (e.g., Serreze et al. 2000). To build stronger foundations for human-dimensions research, we also need empirical studies focusing on responses of contemporary societies to observed variations in climate. Such studies ideally should involve (1) climate-sensitive human activities that are economically or socially important; (2) substantial historical climatic variation; (3) linkage between local variations and global processes; and (4) time series data on both climate and socioeconomic variables. In this paper, we present findings from one such study, focusing on warming winters and the ski industry of New Hampshire.

Skiing comprises a climate-sensitive activity, particularly in regions such as New Hampshire where the difference between good and bad years (or even days) can be large. The ski industry has been an important part of New Hampshire's economy since the 1930s (Allen 1997). From the time leaves fall in autumn until they return in late spring, snow is the state's main tourism draw. As a result, skiing was recently named the official state sport. It generated \$566 million in visitor spending and nearly \$58 million in tax revenue in 2000, accounting for around $10 \%$ of the wintertime jobs (Ski New Hampshire 2002). New Hampshire is among the top five U.S. states in terms of the economic benefit from skiing as a percentage of the state's economy.

Unfortunately, the frequency of poor conditions for skiing in this state has been increasing. We note that changes in New Hampshire winters have taken place in step with global warming trends. As winters grew warmer, the ski industry shifted from expansion to consolidation. An industry historically characterized by many small areas evolved into one dominated by just a handful of large, highly capitalized areas. The timing and geography of this shift suggest that the consolidation was driven partly by climatic pressures, interacting with more obvious social and economic forces. Climatic change favored ski areas with particular geographical advantages and ever-escalating investments. In reshaping the ski-industry landscape, climatic change affected skier experiences and expenditures as well.

In this paper we begin with a description of New Hampshire's winter climate, and the uncertainties this produces for skiing. Warming winters have made ski conditions less predictable and marginalized formerly viable locations. We next review the history of ski areas in New Hampshire, focusing on the many "lost" areas that have come and gone. Time series of temperature and ski-area counts show a notable correspondence. Closures have moved the industry's center of gravity northwards in the state, away from population centers but towards the most reliable snow. Climatic change increased the importance of heavy investment in snowmaking and economic diversification, which left behind nearly all of the smaller ski areas. Some degree of consolidation would certainly have occurred due to non-climate economic forces, but climate directly and indirectly strengthened this trend. These conclusions fit with those of other recent studies on ski industries and, more broadly, the human dimensions of environmental change. 


\section{NEW HAMPSHIRE WINTERS}

"Our three biggest years [in terms of ski revenue] all coincided with a lot of natural snowfall.... Climate, I think, is the number one reason why people go skiing or not." (Ski industry executive, 2002)

Winters in New Hampshire exhibit wild variation, even on small spatial and temporal scales. Snowstorms often change over to rain or vice versa, and rain/ice/snow lines commonly are drawn across weather maps of the state, separating adjacent communities. Year-to-year variations can be dramatic as well, ranging from deep snowdrifts one February to solid ice or dry hillsides the next. Such variations, problematic for the ski industry, relate to four aspects of the state's geography (Keim and Rock 2001).

- At the state's mid-latitude location, halfway between the equator and the north pole, fierce battles rage between warm, moist airmasses from the south and cold, dry airmasses to the north. Fronts passing through bring a change from one airmass to another. Unusual dominance by either warm or cold airmasses produces warm or cold winters, and either liquid or solid precipitation.

- In late winter, sea surface temperatures off the state's southeast coast fall to $2.5^{\circ}-3.0^{\circ} \mathrm{C}\left(36.5^{\circ}\right.$ $-37.4^{\circ} \mathrm{F}$ ). During snowstorms, these waters remain warm relative to land, which influences snow-rain boundaries. It is not unusual for the coastal zone to receive rainfall while snow occurs at some distance inland - with that distance varying dramatically between storms.

- The prevailing westerly winds bring drier continental air from the U.S. and Canada, giving the state a continental rather than maritime climate. It can get cold in the winter because the moderating influence of the ocean is minimized, especially towards the north. When cyclonic storms ("nor'easters") march up the East Coast of the U.S., the region briefly experiences northeast winds. In wintertime, nor'easters often produce blizzards.

- $\quad$ New Hampshire has mountainous topography ranging from sea level to 1917 meters (6288 feet) in elevation. Mountains can enhance precipitation on their windward side, creating drier conditions downwind. Increases in elevation also lead to cooler air temperatures, enhancing either rainfall or snowfall totals.

The rain/ice/snow line thus varies by geography and elevation, sometimes changing rapidly. Northern New Hampshire, generally higher and farther from the sea, receives more snow than the southern part of the state. Figure 1 compares mean monthly snowfall for the cities of Keene, in southern New Hampshire, and Berlin, in the north (see Figure 6 for locations). In northern New Hampshire, December and January are months of maximum snowfall, whereas January forms the distinct peak at most locations in the south. Statewide precipitation is nearly the same in both December and January. In northern New Hampshire, December temperatures are more consistently cold enough to yield snow, hence the higher snowfall totals. In southern New Hampshire, however, more of December's precipitation falls as rain; snow becomes more common in January as temperatures cool. New Hampshire winters also have a tendency to linger into the early spring for reasons explained by Bradbury et al. (forthcoming a), so that March receives almost as much snow as the core winter months. One consequence of these patterns for New Hampshire skiing is that seasonal snowfall accumulation for an 
"average" year begins later and ends sooner in the south than the north, and that New Hampshire winters begin and end later than comparable places in the western United States.

\section{$<<$ Figure 1 about here $>>$}

\section{CLIMATIC TRENDS}

"It doesn't snow like it used to." (Skier looking back on half a century of experience, 2002)

The preceding section described average patterns over a half-century of observations. Wide inter-annual variations in these patterns leave New Hampshire ski areas vulnerable to short-term weather changes, particularly in the south. But longer-term trends towards warmer and less snowy winters have systematically increased pressures on ski area operations. Figure 2 displays the inter-annual variability in New Hampshire winter temperatures (based on Climate Divisional Data from the National Climatic Data Center, see Guttman and Quayle, 1996). Over 1896-2002 (winters of 1895-1896 through 2001-2002) the state's mean winter temperature warmed by $2.1^{\circ} \mathrm{C}\left(3.8^{\circ} \mathrm{F}\right)$. The linear trend is statistically significant $(P<.001)$, and the true warming probably is substantially greater than that shown by these data (Keim et al. submitted). A linear model oversimplifies the story, however. Twentiethcentury warming has been uneven, and most pronounced after 1975. The run of above-average temperatures in the last two decades includes 6 of the 10 warmest winters in a century. The winter of 2001-2002 was the warmest ever recorded.

\section{$<<$ Figure 2 about here $>>$}

The smooth curve in Figure 2 was obtained by locally weighted scatterplot smoothing, or lowess regression, using a bandwidth of 0.5 (Hamilton 2002). This smoothing reveals a global signal. Zweirs and Weaver (2000:2081) observed that:

"Since 1860, global mean surface air temperatures have increased by $0.6 \pm 0.2^{\circ} \mathrm{C}$, but this warming has not been continuous. Most of the warming has occurred during two distinct periods, from 1910 to 1945 and since 1976, with a very gradual cooling during the intervening period."

The global warming, cooling and warming eras they describe apply to New Hampshire as well. Vertical lines in Figure 2 delineate the 1910-1945 warming, gradual 1945-1975 cooling, and 1975-present warming periods. Thus, New Hampshire winters over the past century conform to a global pattern. The cold averages and exceptionally severe winters in the first third of the 20th century have counterparts elsewhere in the Northwest Atlantic (Serreze et al. 2000). As mean winter temperatures rose closer to the melting point in the late 20th century, some ski areas faced threats to their basic resource.

Mean winter precipitation weakly but significantly $(P<.05)$ declined from $1895-1896$ to 2001-2002, by about $1.5 \mathrm{~cm}$ (0.6 inches) (Figure 3). Again, details are nonlinear: most of the decline took place in the first part of the century, so it is not implicated in ski-industry developments. Winter precipitation without sub-freezing temperatures (that is, ice storms and rain) have recently been the bane of New Hampshire skiing.

$<<$ Figure 3 about here $>>$ 
Figure 4 graphs annual snowfall amounts for the cities of Keene and Berlin over the winters of 1950-1951 through 2001-2002. In most years, Berlin's northern location received noticeably more snow. Regression lines show the overall downward trends: Berlin's mean snowfall declined by $43 \mathrm{~cm}$ (17 inches) during this period $(P=.16)$, while Keene's went down $58 \mathrm{~cm}(23$ inches, $P<.05)$. Both trends are unhappy ones for ski areas, but the lower starting point and steeper decline observed at Keene spell difficulties for southern operations. More troubling than the average decline has been the increasing frequency of low-snow winters.

\section{$<<$ Figure 4 about here $>>$}

As with the temperature data in Figure 2, we find that the snowfall data in Figure 4 contain a global signal. These snowfall series correlate negatively $(r=-.4$ or $-.5, P<.01)$ with the winter North Atlantic Oscillation (NAO) index. The NAO index represents a large-scale atmospheric phenomenon in the North Atlantic Basin. In recent years this index has attained historically unprecedented high values, associated with widespread northern-hemisphere climatic changes (Hurrell et al. 1997, 2001; Langenberg 2000; Serreze et al. 2000). The index is defined from differences between sea-level air pressure measured in Iceland and the Azores or Lisbon. A positive-NAO state classically involves a high-pressure anomaly centered over Greenland, with a low-pressure anomaly across the Atlantic to its south. Characteristic wind patterns affect climate around the Atlantic. In their report on climate change, the New England Regional Assessment Group observed that positive NAO is associated with rising coastal water temperatures:

"The winter warming trend in southern New England coastal waters correlates well with the transition from a prolonged negative NAO winter index phase to a positive phase between 1950 and 1990." (2001:24)

Rising NAO also correlates with increasing winter streamflow in New England, which could reflect warmer temperatures and/or precipitation changes (Bradbury et al., forthcoming b). Our analysis extends the NAO connection to snowfall: positive NAO is associated with lower snowfall, which as noted has connections to both water and air temperatures. The NAO-snowfall correlation involves decadal-scale cycles as well as multi-decadal trends. These results support findings of Hartley and Keables (1998) who demonstrate that high (low) New England snowfall is associated with enhanced meridional (zonal) circulation along the East Coast of the United States, indicative of negative (positive) NAO values. Less snowfall, combined with roughly stable precipitation and increasing streamflow, suggests that a larger fraction of winter precipitation now falls in liquid form.

\section{THE LOST SKI AREAS}

"Our niche was with families. We were the place where you could see your kids, and the lift attendants might even know the names of the kids." (Former owner of a small ski area, 2001)

An ancient Scandinavian technology, skis were introduced to New Hampshire by Norwegian immigrants in the late 19th century. Originally, skis served mainly as practical transportation in deep 
snow. A shift towards recreational applications was pioneered by the Dartmouth Outing Club, which promoted events and began ski clubs during the late 1910s and early 1920s (Allen 1997).

The first "ski areas" emerged as avid skiers began to cut ski trails through the woods. Dartmouth club members made descents of the Mount Moosilauke carriage road during the 1920s. In 1932, work began on a ski trail on Cannon Mountain. The following summer the Civilian Conservation Corps cut additional trails at several White Mountain locations. The first rope tow in New Hampshire began operating in 1935, among the earliest such facilities in North America (New England Ski Museum 2002).

From 1935 to 1950 , dozens of new ski areas opened. They typically started on a small scale, then over time invested in new trails, lifts and amenities for their guests. Two major resorts opened in the late 1930s: Cannon Mountain and Mount Cranmore, both still operating today. Cannon possessed a tramway, 654-meter (2146-foot) vertical drop, ski patrol and a ski school. Although Mount Cranmore had less vertical relief (356 meters or 1167 feet) to work with, it would become the first full-amenities ski resort in New Hampshire. A unique lift called a "skimobile" was built, along with base lodging and a resort community modeled after Sun Valley, Idaho (New Hampshire Ski Museum 2002). Other resorts, some much larger, followed in later decades as skiing became a multibillion-dollar industry. Successful ski areas today must offer a high level of service, reliable skiing conditions and fast lifts. Condominiums and other real estate developments play a major role in the business strategies of most.

Over this 70-year history, many ski areas have opened, drawn crowds for a while, then closed down. The New England Lost Ski Areas Project maintains a Web site (NELSAP 2002) dedicated to preserving the history of these vanished but not forgotten areas. At this writing, NELSAP's list includes more than 400 "lost" ski areas, 155 in New Hampshire alone. Many of the lost areas were quite small operations, but they also include some once-substantial enterprises served by chairlifts or even a gondola, with base lodges and real-estate developments. The NELSAP framework provided a starting point for our own database, which we extended using archival and interview data. In addition to NELSAP's lost ski areas, our project database includes the current survivors. For purposes of this analysis, we concentrate on Alpine or downhill skiing, and do not include the fairly recent development of areas specialized in Nordic or cross-country skiing.

Our database is a work still in progress, but we currently have "opening year" and (if closed) "closing year" for 123 New Hampshire downhill ski areas. Three-quarters of these (93) are small enterprises that operated only simple lifts such as rope tows, T-bars or J-bars. The remainder (30) are more substantial. We used the operation of a chairlift or gondola at any time as a criterion to roughly distinguish the smallest areas from those medium-to-large. Rope tows and J-bars are much less expensive than chairlifts. Chairlifts carry more weight uphill, requiring larger engines and heavier cables in addition to high and well-anchored towers. Chairlifts also need more employees both to operate the machinery and to assist skier loading and unloading. Thus in comparing non-chairlift with chairlift areas, we are looking across the beginning of a capital divide that (for the most successful areas) widened enormously over time.

Figure 5 graphs the number of downhill ski areas of each type, chairlift or other, known to be operating in New Hampshire over the years 1930-2001. Despite some missing records, our data are complete enough to show overall trends. We see the proliferation of small areas in the $1930 \mathrm{~s}$, then a 
wartime hiatus. (Several small areas that opened at unknown dates during the 1930s are graphed at "1930," so the starting level of this curve is too high but it becomes more accurate by the decade's end.) A relatively cold, snowy climate did not "cause" the proliferation of small areas in the 1930s and 40s, but rather, was among the conditions that made this proliferation possible. The number of small areas peaked in the early 1950s, and fluctuated not far below that level for the next two decades. After 1970 the number of small areas rapidly declined. Non-climatic factors including an interstate highway that improved access to four large northern resorts, the 1973 energy crisis that created hardships for both skiers and ski areas, and increasing costs of liability insurance contributed to the early-70s decline of small areas.

\section{$<<$ Figure 5 about here $>>$}

The more capital-intensive chairlift areas proliferated at a slower pace, but they continued to increase while small areas struggled and closed in the $1950 \mathrm{~s}, 60 \mathrm{~s}$ and $70 \mathrm{~s}$. The number of chairliftserved ski areas only began to decline in the 1980s. Today 17 chairlift-served areas, ranging from minor local hills to four-season destination resorts, remain in operation. Figure 5 traces a business story of larger ski areas competing more successfully for skiers, and eventually taking over the market. But there are details in the paths of both curves that reflect the influence of climate change as well.

Two vertical lines in Figure 5, at 1945 and 1975, delineate the climate-trend eras described earlier with respect to Figure 2 and global temperatures. Before 1945, temperatures were rising but still generally quite cold. Thus the initial boom of small ski areas occurred at a time when New Hampshire winters were more formidable than today. Put another way, many of these areas were built and found good enough conditions in locations that would later become less practical for natural-snow skiing. A ski area could start up with minimal investment because nature provided all the snow. Thus although social and economic forces drove ski area development, climate made it possible.

A series of warm winters in the 1950s (Figure 2), including three successive low-snow years for southern New Hampshire (Figure 4), coincides with a dip in the number of small areas seen in Figure 5. (The Korean War, 1950-53, probably contributed to the 1950s dip as well.) Subsequently more average conditions prevailed, so that overall the 1945-1975 period saw a slight cooling trend as well as several high-snowfall years. The number of larger areas had grown fourfold by the end of this period, while the number of small areas was rapidly falling.

After 1975, winters began the marked warming trend that continues today, and low-snow years became more frequent. Small areas continued to drop out rapidly. Although non-climatic factors had contributed to the early-70s drop in small areas, a second steep drop in the mid-70s followed several years of declining snowfall and above-average temperatures. Within a few years the number of chairliftserved areas began shrinking as well, for the first time since the ski industry began. By 2002 only 17 chairlift areas remained in operation, and several of these were economically precarious. The strongest ski resorts were those with massive investments in snowmaking and grooming, supported by real-estate developments and year-round diversification programs.

Figure 6 maps the geographical distribution of New Hampshire ski areas at 25-year intervals. Comparing 1925 (no areas) with 1950 shows the early-years proliferation of small areas scattered around the state, with a center of gravity towards the south where most of the population resides. By 1975 many 
of these small areas had closed, while the number of chairlift areas increased. Most of the small and southern areas, along with some larger resorts, are gone by 2000. The center of gravity has shifted towards a handful of large northern resorts. Some northern areas possess a second great advantage besides snow: bigger mountains, allowing vertical drops of 600 meters $(2,000$ feet $)$ or more. The northern disadvantage is distance from population centers including the state's main cities as well as southern New England. Convenience and cost factors associated with this distance should have left a market niche for more southerly areas, if their skiing conditions could compete with the north.

\section{$<<$ Figure 6 about here $>>$}

\section{ADAPTATION TO CHANGE}

"It [the lack of natural snow] got so bad it couldn't be ignored. By 1981-82, it became obvious that if you wanted to stay in the business, you had to have top-to-bottom snowmaking." (Ski historian, 2002)

"[In the 1980s] The larger areas ... were putting a lot of capital into high-speed chairs, fine grooming and snowmaking. And so they were really becoming a class ahead. And as the medium size areas ... tried to compete, they overextended themselves and [in] light economic downturns or bad snow years they had no reserves to back them up." (Snow engineer, 2002)

Artificial snowmaking began spreading among New England ski resorts during the 1960s. In the early years it was largely a novelty, but as technology improved, natural snow became less reliable and skiers increasingly expected a "groomed" product, snowmaking turned into a necessity. Major areas spent millions of dollars on snowmaking equipment during the late 1970s and early 1980s. The successful ones left behind other areas that could not keep up with the pace of investment. Artificial snow can be produced whenever the temperature falls below freezing, so ski areas could add fresh surface and build base depth more or less continuously if desired. Artificially-produced snow is denser than natural snow and melts more slowly in the spring, as well. Snowmaking thus lengthened the ski season while insuring more consistently skiable conditions. Aggressive snowmaking programs became a marketing attraction to draw skiers, who could immediately see the advantages. Today, all of New Hampshire's large ski areas make snow, and on average they can cover more than $90 \%$ of their terrain (Ski New Hampshire 2002).

To support snowmaking, the ski area needs access to a large source of water. Tapping local rivers or lakes expands the ecological footprint of ski areas, and has led to environmental-impact controversies. The availability of water for snowmaking (whether "availability" is limited by environmental, political or economic factors) became another geographical dimension that could help or hurt particular ski areas. Investments in the water source, a pumping system, pipes, energy and the associated personnel add to the formidable costs of large-scale snowmaking. Ski areas had no choice but to make such investments or watch their skiers go elsewhere. Today only a few small community slopes operate without snowmaking. But even for the areas with snowmaking, due to climate change the number of days available to ski has decreased in New Hampshire over the last few decades (Palm 2001). Unseasonably warm weather not only melts the existing snow but reduces the opportunities to make more. 
Competitive ski areas require other substantial investments in addition to snowmaking (Hudson 2000). It has become increasingly desirable to develop summer programs that contribute to year-round income, help maintain core staff and reduce reliance on the unpredictable winter season. Liability insurance has been another area of growing costs. One critical field of investment has been real estate. A ski area can promote adjacent condominium and resort developments that are more profitable than the ski area itself. Lack of prospects for real estate development, for example at areas surrounded by National Forest land, can limit the capital available for new lifts, snowmaking, grooming and other competitive enhancements. Conversely, some condominium developments have been marooned when their ski areas closed.

As ski areas escalated their investments, the cost of a day's skiing rose too. Expensive lift tickets probably reduce the number of visits, and discourage some individuals and families from skiing at all. This likely contributes to the stagnant or contracting number of skier visits reported by many ski areas, despite a growing regional population. Less snowy weather, including less snow in the cities where it would put skiing into people's minds, contributes to the business decline as well. Although some of the economic forces behind ski industry consolidation appear unrelated to climate, warming winters have reinforced other pressures and added to them in indirect ways.

\section{DISCUSSION}

The New England Regional Assessment Group's overview report on climate change in New England puts forth two central conclusions: the regional climate has warmed over the past century; and models project significant warming over the next century (2001:ii). Observational records inform their first point, and computer simulations support the second. In this paper, we have extended their analysis by focusing on New Hampshire's winter climate, where the observed 20th-century changes have been greatest (2001:12). New Hampshire temperature and snowfall trends are not simply local variations, but correlate with changes in global climate. Secondly, we have examined how the climatic record provides a context for reinterpreting the history of New Hampshire's ski industry. The proliferation of small lowinvestment ski areas in the early days, particularly at southern and low-elevation locations, was possible because winters then tended to be snowy and cold. Extinction of the small areas, and concentration of the industry into a few high-investment, high-elevation northern areas, was driven partly by a changing climate. The choices available to skiers have shifted as well, away from their lower-cost options. These observations about historical developments provide an empirical foundation for projecting future change if the climate continues to warm.

Our findings relating New Hampshire climate and the fate of ski areas fit well with Palm's (2001) New-England wide analysis. Palm discovered that 700,000 fewer skier visits occurred during the three worst snow years of the period 1984-2001, as compared with the three best snow years. The lost revenue of low-snow years must have been particularly challenging for areas that were already struggling economically.

Our New Hampshire results also parallel conclusions reached in a study of climate change and ski resorts in Switzerland: 
"If climate change occurs, the level of snow-reliability will rise from $1200 \mathrm{~m}$ up to 1800 $\mathrm{m}$ over the next few decades. Only $44 \%$ of the ski resorts would then be snow-reliable.... Climate change must be viewed as a catalyst that is reinforcing and accelerating the pace of structural changes in tourism." (Elsasser and Bürki 2002:253)

Whereas the Swiss study mainly concerned future climate change, we have examined data from the recent past. That such similar conclusions would arise from studies on different continents, using unrelated methods and data, and with predictive vs. retrospective perspectives, suggests that the conclusions are fairly robust. We suspect that structural changes will be occurring in many other places as global change affects seasonal recreation.

The interdisciplinary approach described in this paper has been elsewhere applied to research on environmental change and North Atlantic fishing communities (e.g., Haedrich and Hamilton 2000; Hamilton and Haedrich 1999; Hamilton and Butler 2001; Hamilton et al. 2000). Fishing communities, like ski areas, meet the four "ideal" criteria discussed earlier for observational research on the human dimensions of climatic change. A recurring theme from this fisheries research applies to ski areas as well: environmental change creates winners and losers. Some ski areas expanded while others closed down during the decades of warming weather. Beyond the ski industry, other enterprises and activities have differentially benefitted or been harmed by climate change as well. We have concentrated here on the role that natural capital (e.g., geography and climate) plays in this process. But other types of capital recognized by social scientists - real capital (investments), human capital (labor) and social capital (including political and entrepreneurial factors) - prove critical too, in determining how things turn out.

Disentangling the impacts of climatic variations from those of other economic and social forces remains a central challenge for observational research on the human dimensions of global change. Where enough data exist, multivariate analysis could be of some help. For example, it might be possible to use survival-analysis modeling to estimate the effects of climatic, geographical, economic and structural variables on individual ski areas. Climatic details such as the timing of extreme weather events or of successive adverse seasons could then be examined, together with economic trends in incomes and consumer spending. This avenue appears promising for future research. 


\section{REFERENCES}

Allen, J. B. 1997. Images of America: New England Skiing. Great Britain: Arcadia.

Bradbury, J. A., S. L. Dingman, and B. D. Keim. forthcoming a. "Relation of New England hydroclimate to large-scale atmospheric patterns." Journal of the American Water Resources Association.

Bradbury, J. A., B. D. Keim and C. P. Wake. forthcoming b. "U.S. East Coast Trough indices at 500$\mathrm{hPa}$ and New England winter climate variability." Journal of Climate.

Elsasser, H. and R. Bürki. 2002. "Climate change as a threat to tourism in the Alps." Climate Research 20:253-257.

Guttman, N. B., and R. G. Quayle. 1996. “A historical perspective on U.S. Climate Divisions.” Bulletin of the American Meteorological Society 77:293-303.

Haedrich, R. L. and L. C. Hamilton. 2000. "The fall and future of Newfoundland's cod fishery." Society and Natural Resources 13:359-372.

Hamilton, L. C. 2002. Statistics with Stata. Belmont, CA: Duxbury.

Hamilton, L. C. and M. J. Butler. 2001. "Outport adaptations: Social indicators through Newfoundland's cod crisis." Human Ecology Review 8(2):1-11.

Hamilton, L. C. and R. L. Haedrich. 1999. "Ecological and population changes in fishing communities of the North Atlantic Arc.” Polar Research 18(2):383-388.

Hamilton, L. C., P. Lyster and O. Otterstad. 2000. "Social change, ecology and climate in 20th century Greenland." Climatic Change 47(1/2):193-211.

Hartley, S. and M. J. Keables. 1998. "Synoptic associations of winter climate and snowfall variability in New England, USA, 1950-1992.” International Journal of Climatology 18:281-298.

Hudson, Simon. 2000. Snow Business: A Study of the International Ski Industry. London: Cassell.

Hurrell, J. W., Y. Kushnir and M. Visbeck. 2001. “The North Atlantic Oscillation.” Science 291(5504):603-605.

Hurrell, J. W. and H. Van Loon. 1997. "Decadal variations in climate associated with the North Atlantic Oscillation." Climatic Change 36:301-326. 
Keim, B. D., A. Wilson, C. P. Wake and T. Huntington. submitted. "Are there spurious trends in the National Climatic Data Center Climate Division Database? An example of potential problems from New England." Geophysical Research Letters.

Keim, B. D, and B. Rock. 2001. “The New England Region's Changing Climate.” Chapter 2 in: Preparing for a Changing Climate: The Potential Consequences of Climate Variability and Change. The New England Regional Assessment Overview. The U.S. Global Change Research Program: University of New Hampshire, pp. 8-17.

Langenberg, H. 2000. “Oscillating opinion.” Nature 408(21/28 December):924-925.

National Climate Data Center (FTP site). 2002. ftp://ftp.ncdc.noaa.gov/pub/data/cirs/

NELSAP (New England Lost Ski Areas Project, Web site). 2002. http://www.nelsap.org

New England Regional Assessment Group. 2001. Preparing for a Changing Climate: The Potential Consequences of Climate Variability and Change. Durham, NH: University of New Hampshire.

New England Ski Museum (Web site). 2002. http://skimuseum.org

Palm, B. T. 2001. Skiing with Climate Change: An Analysis of Climate Change and the Consequences for the Ski Industry in New Hampshire and Vermont. Doctoral Dissertation: Oxford University.

Serreze, M. C., J. E. Walsh, F. S. Chapin III, T. Osterkamp, M. Dyurferov, V. Romanovsky, W. C. Oechel, J. Morison, T. Zhang and R. G. Barry. 2000. "Observational evidence of recent change in the northern high-latitude environment." Climatic Change 46:159-200.

Ski New Hampshire (Web site). 2002. www.skinh.com/programs/ofstate.htm

Zwiers, F. W. and A. J. Weaver. 2000. “The causes of 20th century warming.” Science 290:2081-2083. 


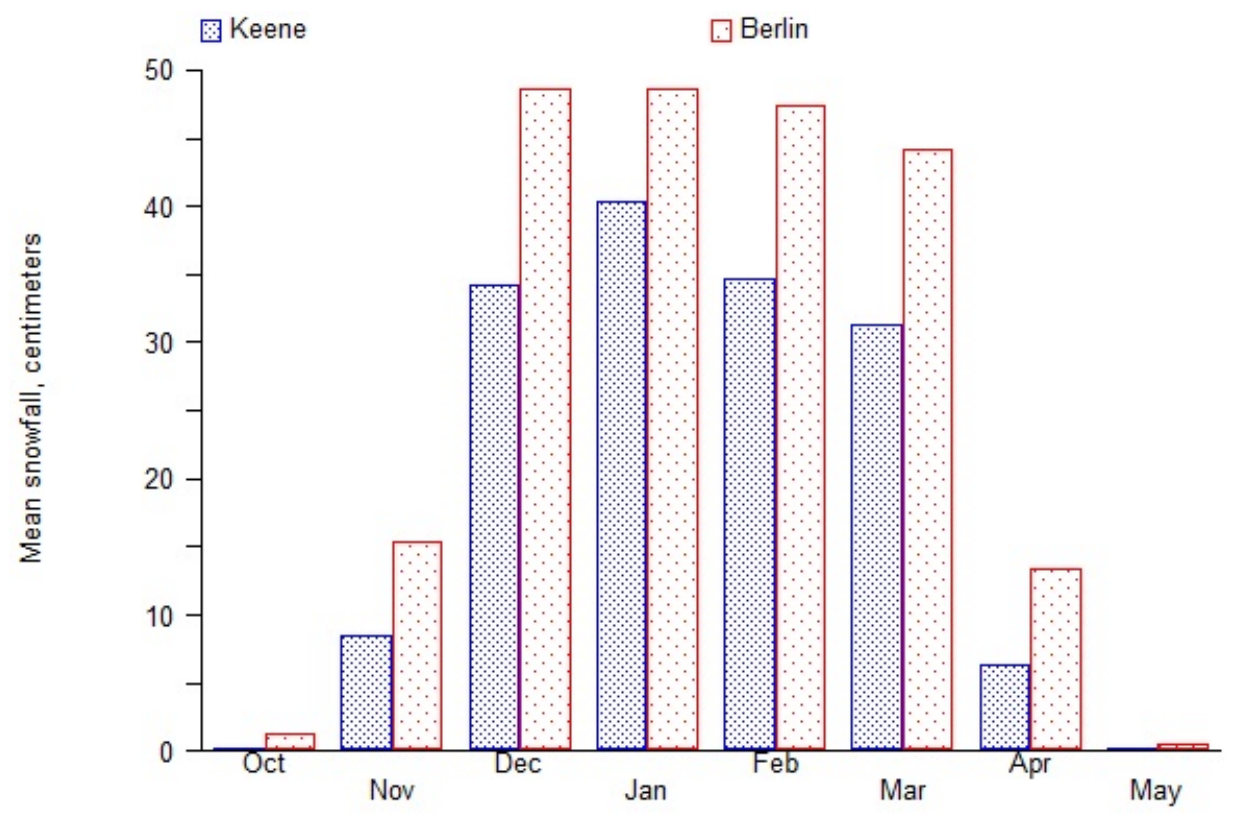

Figure 1: Mean snowfall by month for the New Hampshire cities of Keene (south) and Berlin (north), based on records from the winters of 1950-1951 through 2001-2002. 


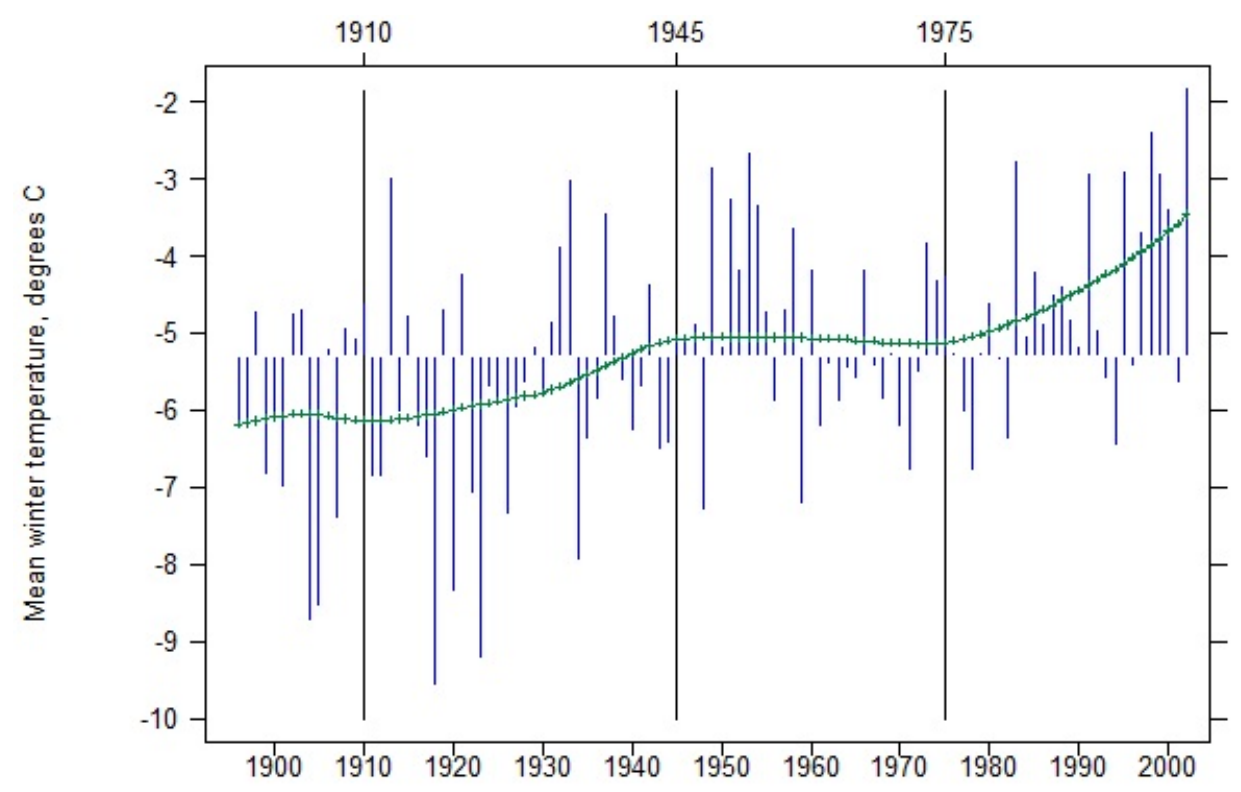

Figure 2: New Hampshire winter mean temperature, 1896-2002. Annual December-March values as mean deviations, and lowess regression curve showing multi-decade trends.

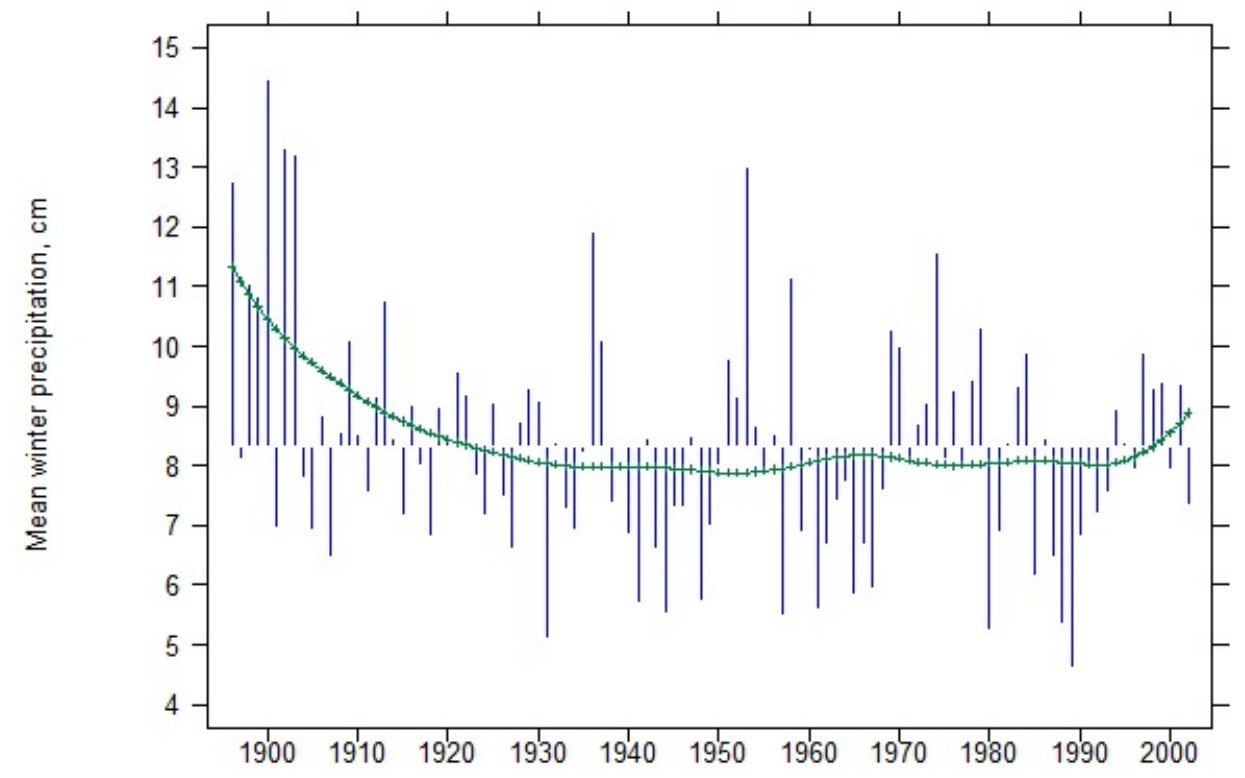

Figure 3: New Hampshire winter mean precipitation, 1896-2002. Annual mean deviations, and lowess regression smoothed trend. 


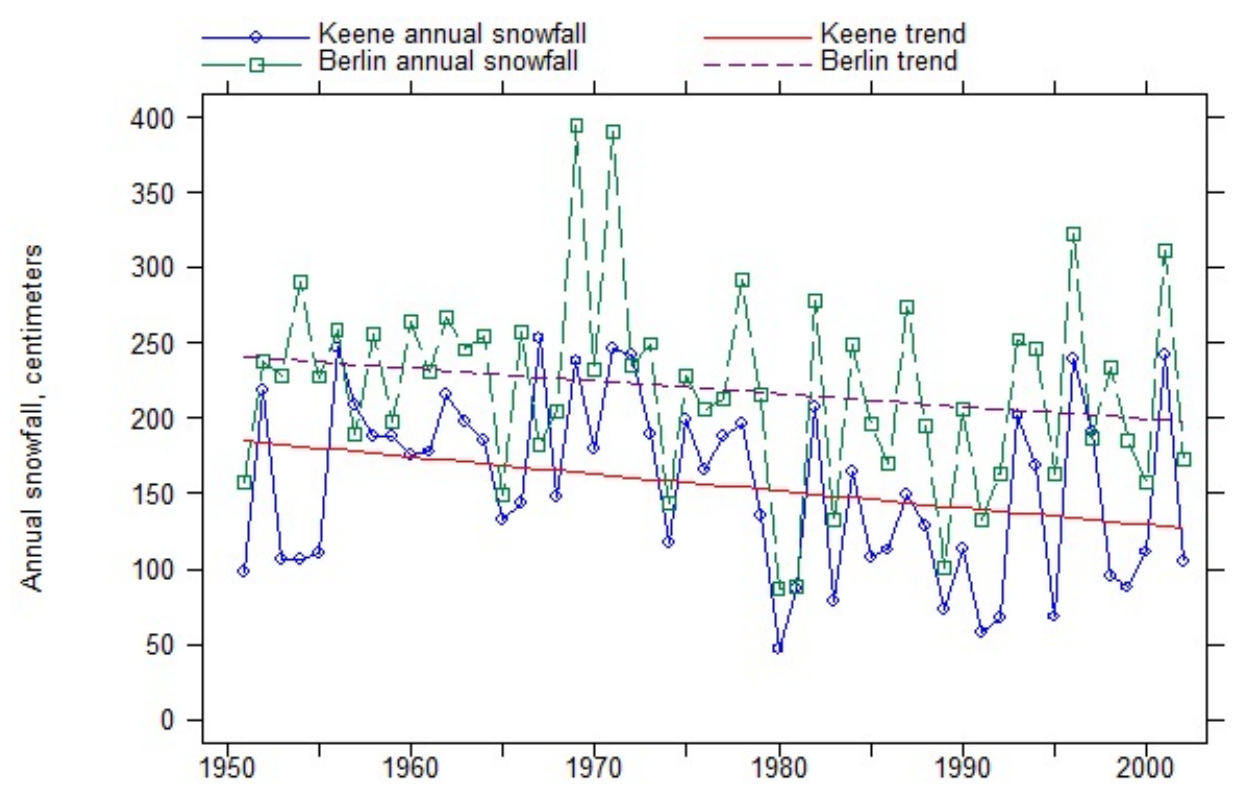

Figure 4: Snowfall in Keene (south) and Berlin (north), 1951-2002. Seasonal totals and linear trends (OLS regression).

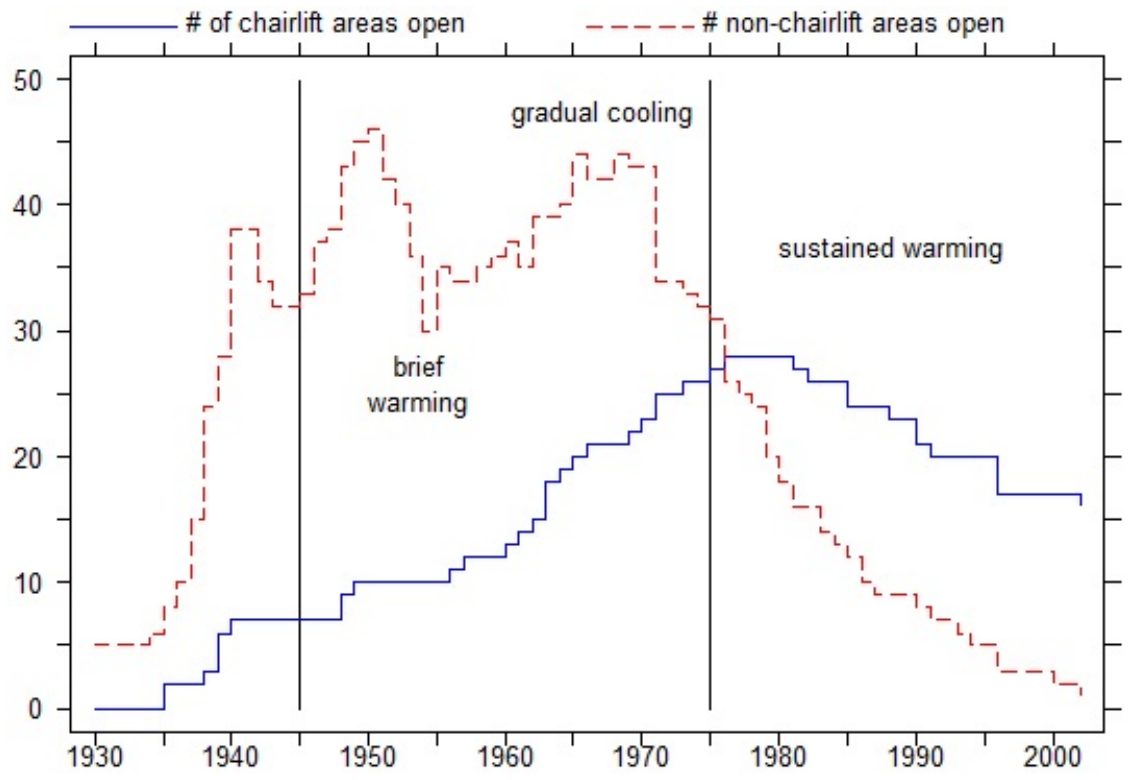

Figure 5: Number of known downhill ski areas operating in New Hampshire, 1930-2002. Small areas that never possessed a chairlift or gondola are shown separately (dashed line). 